\title{
IN VIVO COMPARISON OF THE EFFECTS OF RHBMP-2 AND RHBMP-4 IN OSTEOCHONDRAL TISSUE REGENERATION
}

Yaiza Lópiz-Morales $^{1 \#}$, Ander Abarrategi ${ }^{2,3 \#}$, Viviana Ramos ${ }^{3}$, Carolina Moreno-Vicente ${ }^{2}$, Luis López-Durán ${ }^{1}$, José Luis López-Lacomba ${ }^{2 *}$ and Fernando Marco ${ }^{1}$

${ }^{1}$ Hospital Clínico San Carlos. Calle Profesor Martín Lagos s/n. (28040) Madrid, Spain.

${ }^{2}$ Instituto de Estudios Biofuncionales. Universidad Complutense. Paseo Juan XXIII, 1. (28040) Madrid, Spain.

${ }^{3}$ Noricum S.L. Departamento de I+D. Parque Científico de Madrid. C/ Santiago Grisolía 2. (28760) Tres Cantos, Spain.

\# Yaiza Lópiz-Morales and Ander Abarrategi contributed equally to the paper.

\begin{abstract}
The aim of this work is to investigate the use of bone morphogenetic proteins (rhBMP-2, rhBMP-4) alone or in combination with cells delivered in a calcium alginate gel for the treatment of osteochondral defects. For this purpose, alginate gels were prepared mixing a $2 \%$ sodium alginate solution and a $200 \mathrm{mM}$ calcium chloride solution (1:1). Osteochondral defects were created ( $4 \mathrm{~mm}$ wide, $5 \mathrm{~mm}$ deep) in the internal femoral condyle of rabbit knee and gels were directly formed into the defects. 3 months after surgery samples were harvested, gross morphology was documented and histological appearance was evaluated. The performed histological observations revealed subchondral bone regeneration in rhBMP-2 samples and moderate hyaline cartilage regeneration in rhBMP-4 samples. Thus, results indicate that alginate gel may serve as an appropriate delivery vehicle for rhBMP-2, rhBMP-4 and stromal cells. With this carrier material, differential behaviour between the evaluated proteins was observed. rhBMP-2 shows better restoration of subchondral bone in contrast to the superior efficiency of rhBMP-4 for hyaline cartilage repair.
\end{abstract}

Keywords: Biomaterials, cartilage, in vivo, BMP signalling, tissue engineering.

\footnotetext{
*Adress for correspondence

José Luis López-Lacomba

Instituto de Estudios Biofuncionales

Paseo Juan XXIII, 1 (28040) Madrid, Spain

Telephone Number: 34913943288

FAX Number: 34913943284

E-mail: lacomba@farm.ucm.es
}

\section{Introduction}

A variety of clinical procedures have been developed to repair articular cartilage defects, but success has been limited. Restoration of articular cartilage continues to pose a difficult problem to the orthopaedic surgeon because a treatment that enables full restoration of injured articular cartilage to its original state is not yet known (Mierisch et al., 2002). Ability of adult cartilage to regenerate is limited due to its avascularity, the poor mitotic capacity of chondrocytes and the absence of stem cells in this tissue (Buckwalter et al., 1997). Injuries of the joint surface that do not penetrate the subchondral bone have only a minimal healing response and may progress to post-traumatic osteoarthrosis (O'Driscoll et al., 2001). Defects that extend into the subchondral bone allow for formation of a fibrous or fibrocartilaginous tissue with biochemical and biomechanical properties different from hyaline cartilage that undergoes premature degeneration (Marco et al., 1992). Tissue engineering based on cell and growth factors is one of the most promising new approaches by which to repair various tissues, including articular cartilage (Nesic et al., 2006).

Many different types of biomaterials have been tested in vitro, as well as in experimental animals and in human patients, in order to facilitate or promote the repair of cartilage lesions. Scaffolds are used not only as passive material, allowing the surrounding tissue ingrowth and participate in the repair procedure, but also with active role, as carriers for both cells and growth factors (Grande et al., 1997; Lee et al., 2007; Malafaya et al., 2007; Melrose et al., 2008; Sohier et al., 2008; Abarrategi et al., 2010). The summary of all this experience is that the choice of the material is critical for the success of tissue engineering approaches in cartilage repair procedures. This work employed alginate as growth factor and cell carrier. Alginates are naturally derived polysaccharides that have been used extensively in cell and/or growth factor encapsulation, cell transplantation, and tissue engineering applications (Diduch et al., 2000; Mierisch et al., 2002; Mierisch et al., 2003; Chawla et al., 2007; Hannouche et al., 2007). Alginates are composed of Dmannuronic acid and L-guluronic acid. Divalent cations such as calcium create ionic interchain bridges of adjacent alginate molecules, which cause gelling of an aqueous alginate solution.

Cells are widely used in osteochondral approaches due to their role in the new tissue formation. The variety of 
cells available for use in cartilage tissue engineering ranges from undifferentiated mesenchymal stem cell (MSC) from bone marrow or adipose tissue origin to well-differentiated chondrocytes. Also cell-based cartilage repair is increasing in the clinical use. However, the variety of used cells suggests that there is not a consensus about the perfect cell for osteochondral tissue repair (Grande et al., 1989; Raghunath et al., 2005).

Administration of growth factors that can enhance cartilage healing is another important facet of cartilage repair. Local application of growth factors is preferred to avoid systemic toxicity, but the concentration and rate of release of the growth factor at the site of injury has been difficult to determine and to control. Several growth factors, including transforming growth factor (TGF), bone morphogenetic proteins (BMPs), insulin-like growth factor 1 , and basic fibroblast growth factor, can improve chondrocyte proliferation and extracellular matrix (ECM) synthesis in vitro and in vivo (van den Berg et al., 2001; Van der Kraan et al., 2002). Studies performed in vitro and in vivo have led to the identification of rhBMP-2 and rhBMP-4 as promising candidates for the promotion of chondrogenesis. Both of them have been shown to play a role in chondrocyte differentiation and matrix maturation (Luyten et al., 1994; Miljkovic et al., 2008).

The aim of the present work is to investigate the use of these proteins (rhBMP-2, rhBMP-4), alone or in combination with cells trapped in calcium alginate gel for the treatment of osteochondral defects.

\section{Materials and Methods}

\section{Bone morphogenetic proteins (rhBMP-2 and rhBMP-4)}

E. coli produced recombinant human rhBMP-2 (rhBMP2) and rhBMP-4 (rhBMP-4) were generously supplied by Noricum S.L. (Tres Cantos, Spain). The biological activity of both rhBMP-2 and rhBMP-4 was tested in vitro measuring the Alkaline Phosphatase activity (ALP) induced on $\mathrm{C} 2 \mathrm{C} 12$ cells as previously described (Abarrategi et al., 2009).

\section{Cell Cultures}

Rabbit stromal cells were obtained from femur bone marrow as previously described (Tsutsumi et al., 2001). Briefly, both ends of the femurs of each rabbit were removed at the level of the epiphysis, and the marrow plugs were flushed out and homogenised using a cell culture medium (DMEM in high glucose, containing 15\% foetal bovine serum (FBS), $100 \mathrm{U} / \mathrm{ml}$ penicillin, $100 \mu \mathrm{g} / \mathrm{mL}$ streptomycin and 2,5 $\mu \mathrm{g} / \mathrm{mL}$ amphotericin). Cells were placed in tissue culture flasks. The medium was changed after the first $48 \mathrm{~h}$ and subsequently every three days. After 10-14 days, a confluent cell monolayer was obtained. Subsequent routine passaging was done at $80 \%$ of confluence and at an initial cellular density of 5000 cells/ $\mathrm{cm}^{2}$. The culture medium was changed every two to three days.

\section{Preparation of alginate gels}

For the preparation of alginate gels we employed a $2 \%$ sodium alginate solution (Sigma, St. Louis, MO, USA) in phosphate buffered saline (PBS). We also employed 200 $\mathrm{mM}$ calcium chloride solution (Sigma ${ }^{\circledR}$ ) in acetic acid 50 $\mathrm{mM}$. Both solutions were mixed 1:1 and after 30 seconds, the alginate gel was obtained. When used: Stromal cells were resuspended in the alginate solution prior to gelation; BMPs were firstly solubilised in acetic acid (AcH) $50 \mathrm{mM}$ $(\mathrm{pH} 3.5)$ and later mixed with the alginate solution, prior to gelation.

\section{Cellular assays}

Cells obtained in routine passaging were centrifuged and washed twice with PBS. The final cell pellet was resuspended in an alginate solution ( $2 \%$ alginate in PBS). $50 \mu \mathrm{L}$ of this alginate solution, containing $1 \times 10^{6}$ cells, were gelled directly into each well of a 48 well tissue culture plate, by the addition of $50 \mu \mathrm{L}$ of a calcium chloride solution (200 mM in AcH $50 \mathrm{mM}$ ). Alginate solutions with rhBMP-2 and rhBMP-4 $(15 \mu \mathrm{g} / 50 \mu \mathrm{L})$ were also assayed. After gelling, the remaining medium was removed and cell culture medium was added.

Cell viability was checked with LIVE/DEAD®, Viability/Cytotoxicity assay (Molecular Probes, Eugene, OR, USA). This assay determines the intracellular esterase activity and plasma membrane integrity. This assay uses the green fluorescent polyanionic dye calcein, which is retained within live cells. It also uses the red fluorescent ethidium homodimer, which can enter cells only through damaged membranes to bind to nucleic acids but is excluded by the intact plasma membrane of live cells. Briefly, Cell culture medium was removed and $100 \mu \mathrm{L}$ of PBS supplemented with $2 \mu \mathrm{M}$ Calcein AM and $2 \mu \mathrm{M}$ Ethidium homodimer were added. Plates were stored $1 \mathrm{~h}$ in the dark at $37^{\circ} \mathrm{C}$. Then, materials were transferred to microscope slides and fluorescence was observed in a Fluorescence microscope (Olympus BX51; Olympus, Tokyo, Japan). Assays were performed in independent samples at 4 and 7 culture days.

Cell viability was quantified by alamarBlue ${ }^{\circledR}$ assay (Biosource, Camarillo, CA, USA). The active ingredient of this assay (resazurin) is a nontoxic, cell permeable compound that is blue in colour and virtually nonfluorescent. Upon entering cells, resazurin is reduced to resorufin, which is also cell permeable and produces very bright red fluorescence, generating a quantitative measure of viability. Briefly, cell culture medium was removed. $400 \mu \mathrm{L}$ of fresh culture medium and $40 \mu \mathrm{L}$ of alamar blue reagent were added to each well. After incubation $\left(1 \mathrm{~h}\right.$ at $37^{\circ} \mathrm{C}$ and $\left.5 \% \mathrm{CO}_{2}\right)$ medium was transferred to new plate and fluorescence was measured (excitation wavelength $540 \mathrm{~nm}$, emission wavelength 590 nm) (Biotek FL-600; Biotek, Arcugnano Vicenza, Italy). Blank readouts were subtracted from measures. Assays were performed in independent samples and in a time course.

\section{Animals and surgical procedure}

Surgical procedures and animal care were performed in compliance with the regulations of the National Institutes 
of Health of the European Union States Public Health Service with the approval of the institution's Animal Care and Use Committee, and they were done under supervision of a licensed veterinarian. 26 New Zealand White (NZW) rabbits housed individually in cages were used for the study with an initial weight between 2.3-2.9 $\mathrm{Kg}$ and about 5 months old. Animals were anaesthetised with a mixture of xylazine (Rompum $\left.{ }^{\circledR}\right)(3 \mathrm{mg} / \mathrm{kg})$, ketamine (Ketolar $\left.{ }^{\circledR}\right)$ $(80 \mathrm{mg} / \mathrm{kg})$ and atropine sulphate (Atropina Braun $\left.{ }^{\circledR}\right)(1$ $\mathrm{mg} / \mathrm{kg}$ ) delivered by intramuscular injection. Before surgical procedure, knees were shaved, prepared and draped in a sterile fashion. In each knee the following procedure was used: A medial parapatellar incision was made in each knee and the patella was dislocated laterally. An osteochondral defect ( $4 \mathrm{~mm}$ wide by $5 \mathrm{~mm}$ deep) was created, in the weight-bearing area of the internal femoral condyle (Kyphon ${ }^{\circledR}$ manual drill). The defect was accurately rinsed with a sterile physiological saline $(\mathrm{NaCl}$ $0.9 \% \mathrm{w} / \mathrm{v}) .5 \mu \mathrm{L}$ of an alginate solution $(2 \%$ in PBS) were gelled directly into each defect by the addition of $5 \mu \mathrm{L}$ of a calcium chloride solution ( $2 \mathrm{mM}$ in $\mathrm{AcH} 50 \mathrm{mM}$ ), giving a construct perfectly inserted and adherent to the subchondral bone and to the cartilaginous border. After gelation, the dislocation of patella was reduced and the knee joint was sutured in layers. When used, Stromal cells (1x10 $0^{6}$ cells/defect) and BMPs $(15 \mu \mathrm{g} / \mathrm{defect})$ were added as described (see "Preparation of alginate gels" section).

For 7 days after surgery, animals received daily 250 $\mathrm{mg}$ of cephazolin. Rabbits were kept in separate cages and were allowed to move freely. At 12 weeks post-surgery, animals were euthanized by intravenous injection of 100 $\mathrm{mg} / \mathrm{kg}$ of sodium pentobarbital. Knee joints were exposed, samples were harvested, images were obtained and samples were fixed in $4 \%$ formalin.

\section{Histology}

For histological evaluation specimens were decalcified with $10 \%$ and $5 \%$ nitric acid for 3 and 2 days, respectively. Samples were paraffin embedded and then $4 \mu \mathrm{m}$ thick sections were cut from the paraffin blocks. Different histochemical stainings were carried out (Hyllested et al., 2002): Conventional haematoxylin-eosin staining; collagen stainings (Masson's trichrome, Reticulin and Sirius red); and Proteoglycan stainings (Safranin O and Toluidin Blue). All histological processing was performed by Dominion Pharmakine histological services (www.pharmakine.com). Images were obtained using an Olympus BX51 microscope.

\section{Histomorphometry}

All the different tissues observed in the defect area were measured. Each region of interest (ROI) was manually selected. Safranin O and Toluidin Blue stainings were used to measure cartilage and fibrocartilage tissues. Measurements were performed on $2 x$ images with Olympus CellD Imaging software. Data are provided in $\mathrm{mm}^{2}$ (mean and standard deviations). One-way ANOVA study with Bonferroni's Multiple Comparison Test was performed (statistical significance between treatments: $p<0.05)$.

\section{Treatment groups and nomenclature}

2 untreated knees were used as Standard of osteocartilage tissue (S); 6 were the Empty control defects (E); 7 defects were filled with Alginate gel alone (A); 5 defects with Alginate containing Cells (AC); 6 defects with Alginate and rhBMP-2 (A2); 6 defects with Alginate and rhBMP-4 (A4); 6 defects with composites Alginate-rhBMP-2 and Cells (A2C) and; another 6 with Alginate-rhBMP-4 and Cells (A4C) . Finally 10 defects were filled with Alginate and both BMPs (A24).

\section{Results}

\section{In vitro study of the implantable material}

Fig. 1A shows the appearance of an alginate gelled in vitro. These gels were used for the immobilization of both growth factors (rhBMP-2, rhBMP-4) and stromal cells. Cell viability was checked with the LIVE/DEAD ${ }^{\circledR}$ assay and Fig. 1 shows micrographs of cell seeded alginate gels (AC), Alginate and rhBMP-2 gels (A2C), and alginate and rhBMP-4 gels (A4C), on the $7^{\text {th }}$ culture day. In all cases mainly viable cells were observed and few red fluorescence points, which correspond to nuclei of dead cells. Fig. 1 also shows the quantitative assays performed (alamarBlue ${ }^{\circledR}$ assay). They show that cells are viable in the alginate gels and in culture at least during 7 days. No differences were observed in cell viability due to the addition of any of the rhBMPs.

\section{In vivo study: Gross morphology study of the articular cartilage}

Fig. 2 shows the surgical procedure for osteochondral defect formation and subsequent alginate filling. 3 months after surgery, the synovial fluid and synovium of knee appeared normal in 56 joints (note that 2 samples corresponding to the $\mathrm{AC}$ treatment were not included in the final study. They contained pus in both knees with a positive culture for Staphylococcus aureus). All filled defects (50 samples) had an opaque appearance and the surface was smooth and regular (Fig. 3).

\section{Histological study}

Haematoxylin-eosin was used as non-specific staining to perform an initial quick morphological assessment (Fig. 4). No tissue formation (empty space) could be observed in E treatment. In other treatments the defect is fully filled with newly formed tissue which means that alginate material disappears. Alginate treatment (A) shows fibrous tissue in the defect area with no bone regeneration (AC was similar, not shown). rhBMP-2 treatment (A2) and A2C show defect fully filled with bone tissue. In contrast, rhBMP-4 treatment (A4) shows poor subchondral bone formation and moderate cartilage regeneration in the defect area. A4C shows better subchondral bone formation and A24 shows both subchondral bone and cartilage regeneration, even if some fissures can be observed in newly formed cartilage.

Fig. 5 shows the reticulin staining which shows collagen fibres. These are related with fibrillar tissue, 

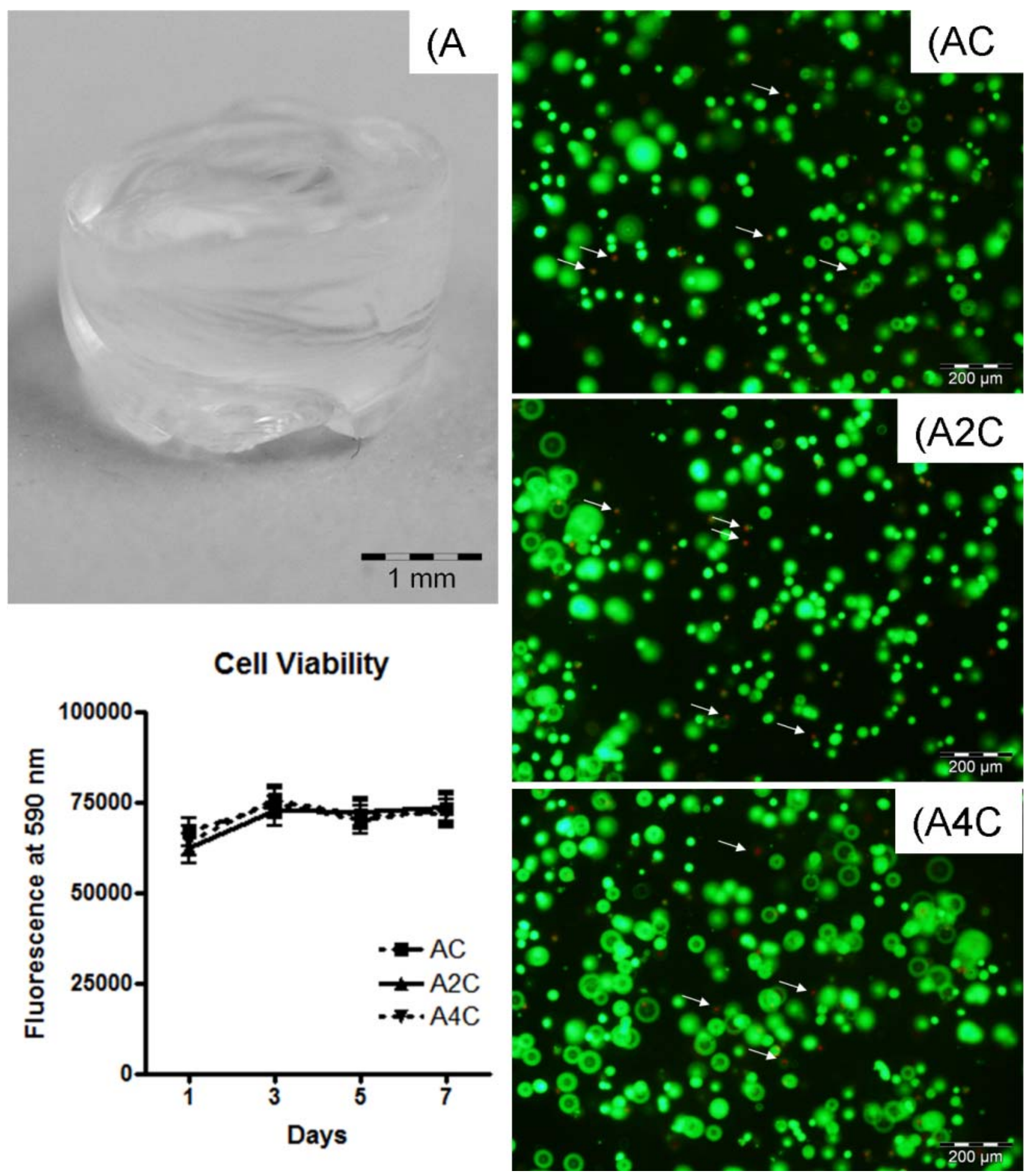

Fig. 1. Cellular assays. A) An example of an alginate gelated in vitro. Microphotographs show combined cell viability/death stain of embedded cells at seven culture day in alginate (AC), alginate and rhBMP-2 (A2C), and alginate and rhBMP-4 (A4C). Green fluorescence corresponds to calcein vital staining and red fluorescence corresponds to nucleus of dead cells (see white arrows). Graph shows a time course quantitative measurement of cell viability for the three treatments (A, A4C and A2C).

pannus and inflammatory responses. Intact tissue $(\mathrm{S})$ is included in the figure for comparative purposes. In $\mathrm{E}$ (Empty), A (Alginate) and AC (Alginate with cells, not shown) treatments the collagen fibres appears, showing a clearly disorganized tissue in the defect area when compared with control intact sample (S). This data suggests that the tissue formed in the defect area of these control groups corresponds to fibrillar tissue. In all other treatments these collagen fibres were not present (data not shown).
Fig. 6 shows another 2 collagen staining: Sirius red staining (up) and Masson's trichrome staining (down). These two alternative stainings are provided in order to visualise collagen with different contrasts, as it was not possible to perform the collagen II immunohistochemistry due to performed sample processing. Same samples are shown in both staining with comparative purposes. Intact tissue $(\mathrm{S})$ is included in the figure as control. Alginate treatment (A) shows cell filled effect and the distribution 


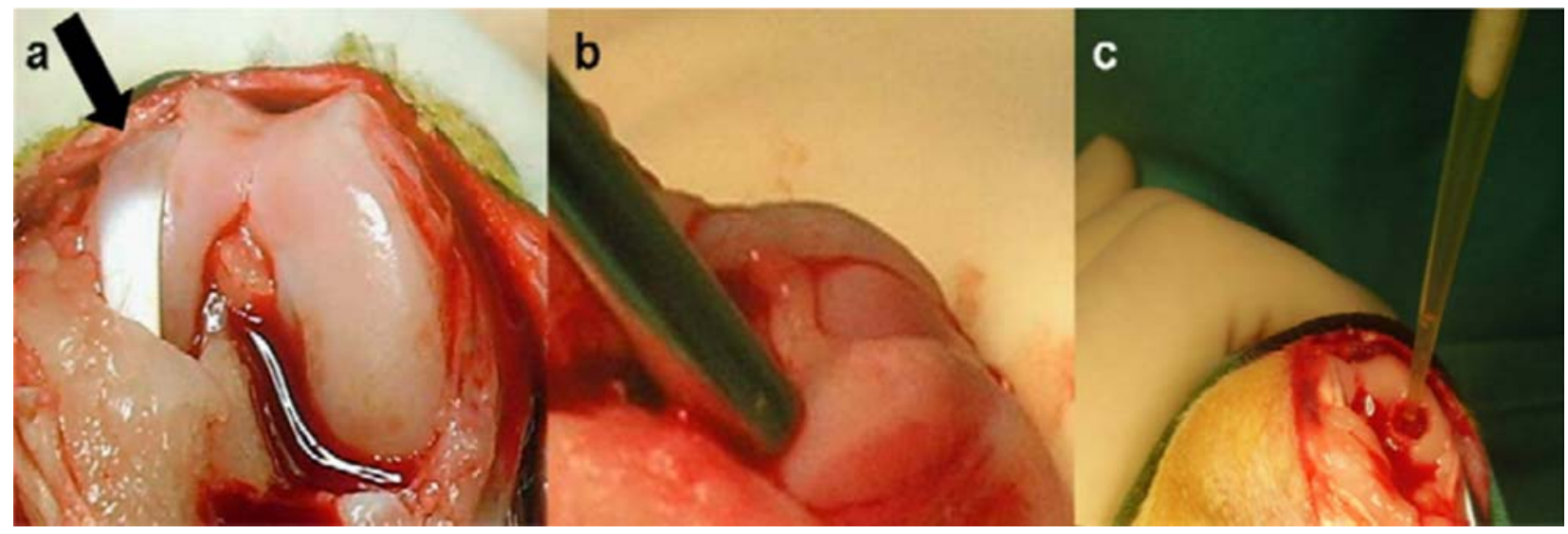

Fig. 2. Surgical Procedure. a) Condylar exposition (arrow: extensor digitorum longus tendon), b) Defect creation, c) In situ alginate gelation.

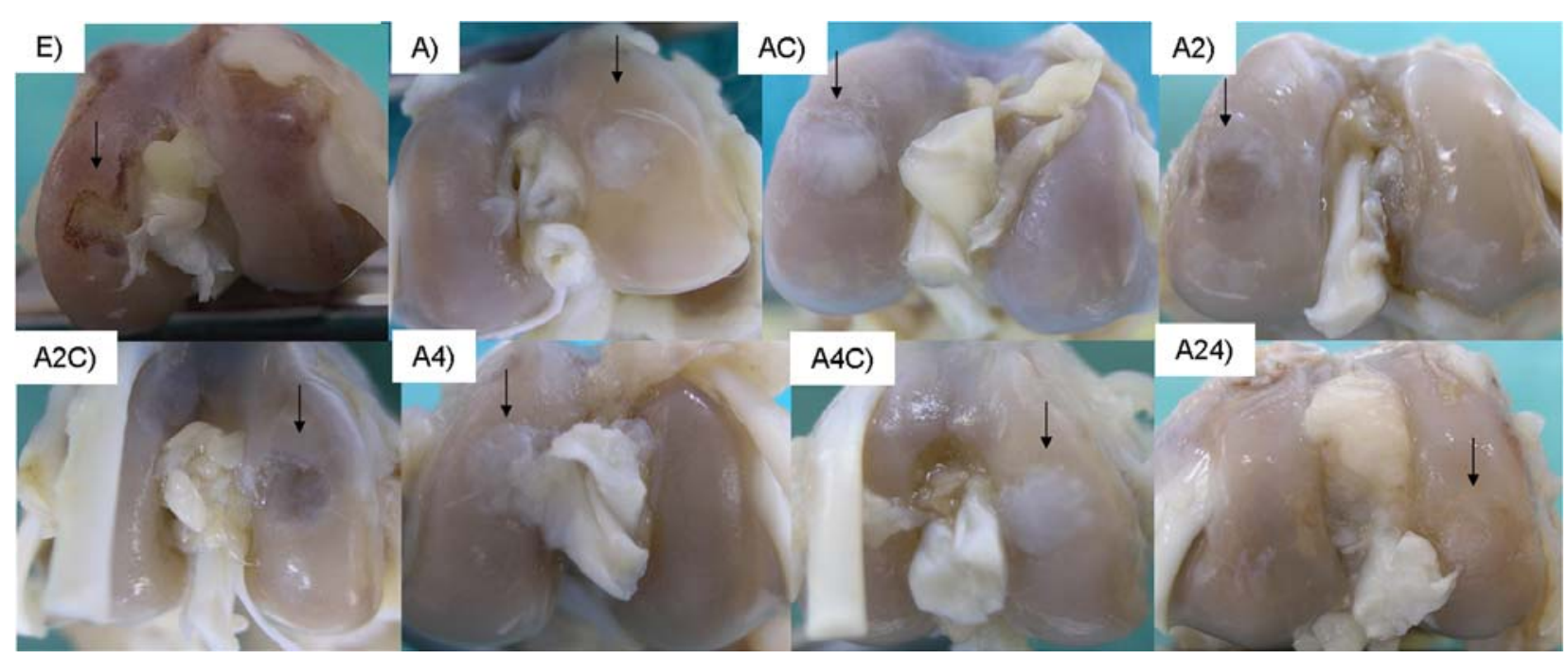

Fig. 3. Macroscopic appearance three months after surgery. E) Empty control, A) alginate gel, AC) alginate and cells, A2) alginate and rhBMP-2, A2C) alginate and rhBMP-2 and cells, A4) alginate and rhBMP-4, A4C) alginate and rhBMP-4 and cells, A24) alginate and rhBMP-2 and rhBMP-4 (arrow: defect area).
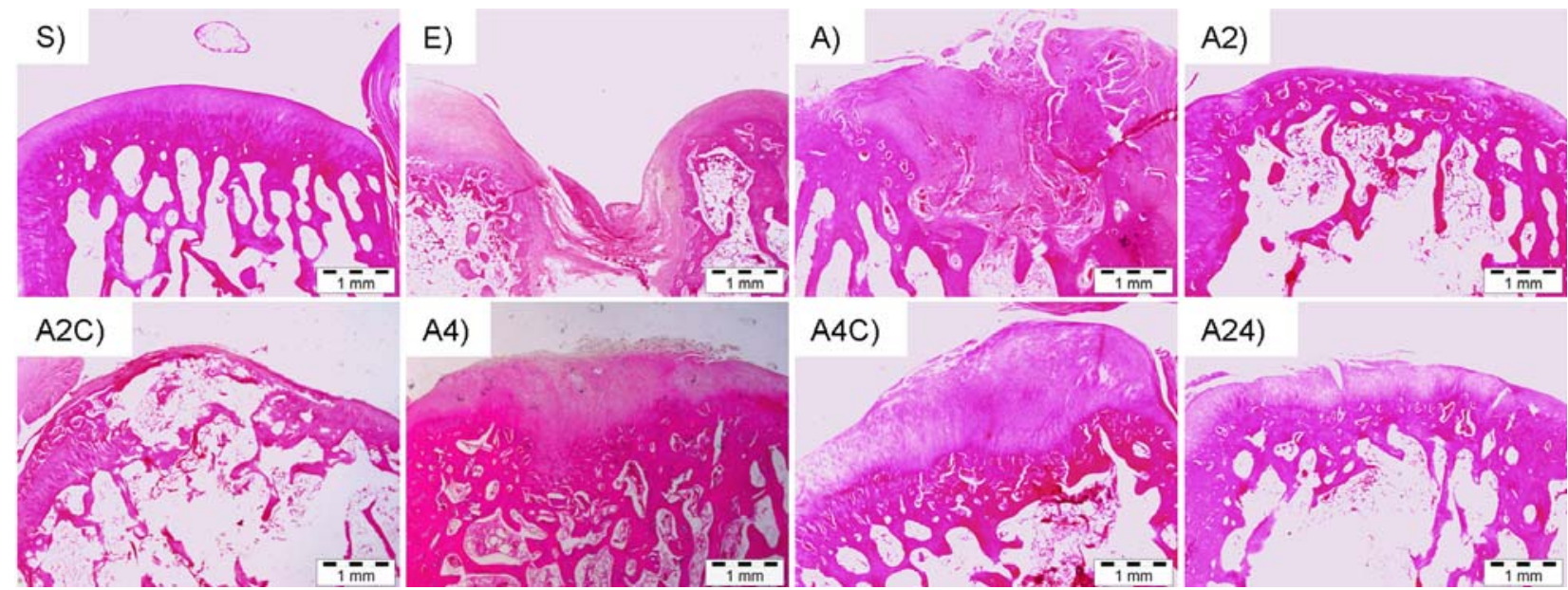

\section{A4)}

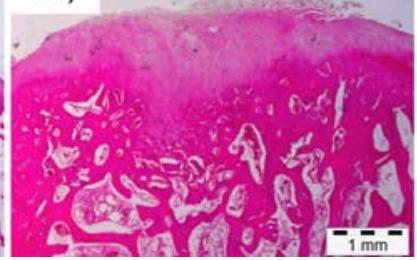

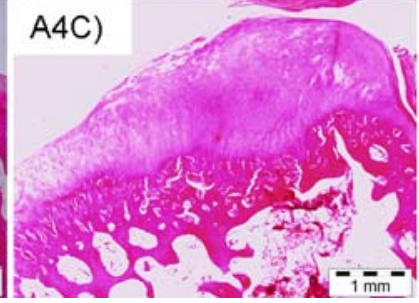

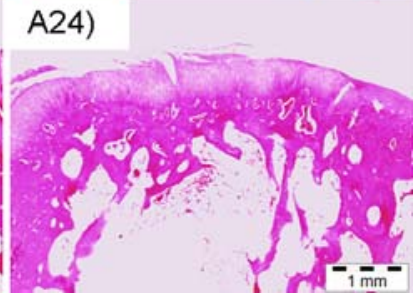

Fig. 4. Haematoxylin-Eosin Staining. S) Control untreated condyle. E) Empty defect. A) Alginate. A2) Alginate and rhBMP-2. A2C) Alginate and rhBMP-2 and cells. A4) Alginate and rhBMP-4. A4C) Alginate and rhBMP-4 and cells. A24) Alginate rhBMP-2 and rhBMP-4. 
S)

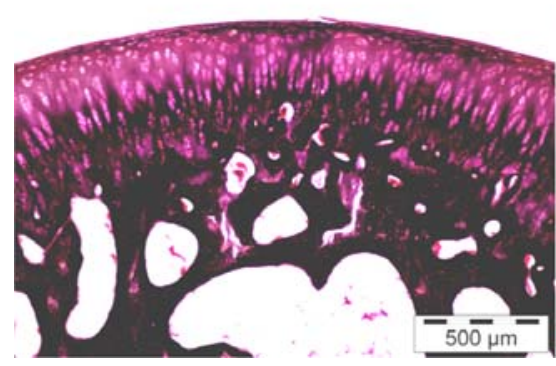

A) $t$ tryat

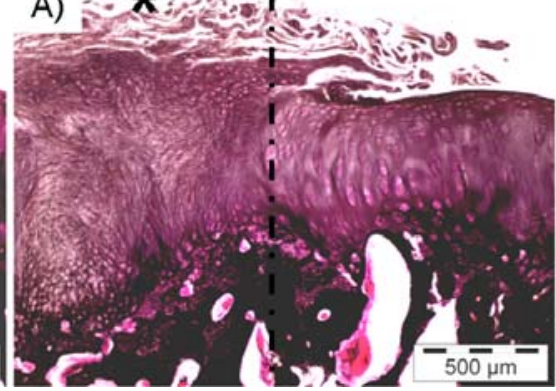

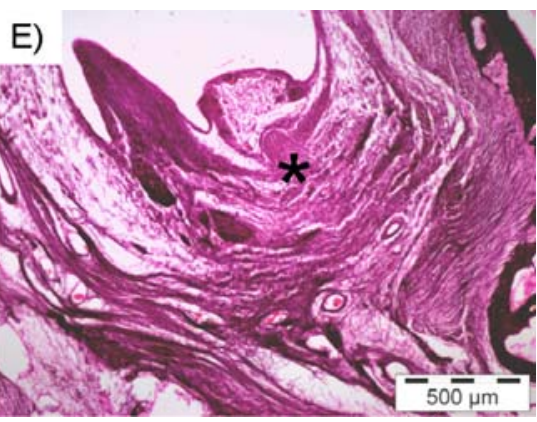

Fig. 5. Reticulin staining. S) Control untreated condyle. A) Alginate. E) Empty defect, tissue formed deep inside the defect. Dotted lines represent the limit of the injury. Asterisk shows the defect area.
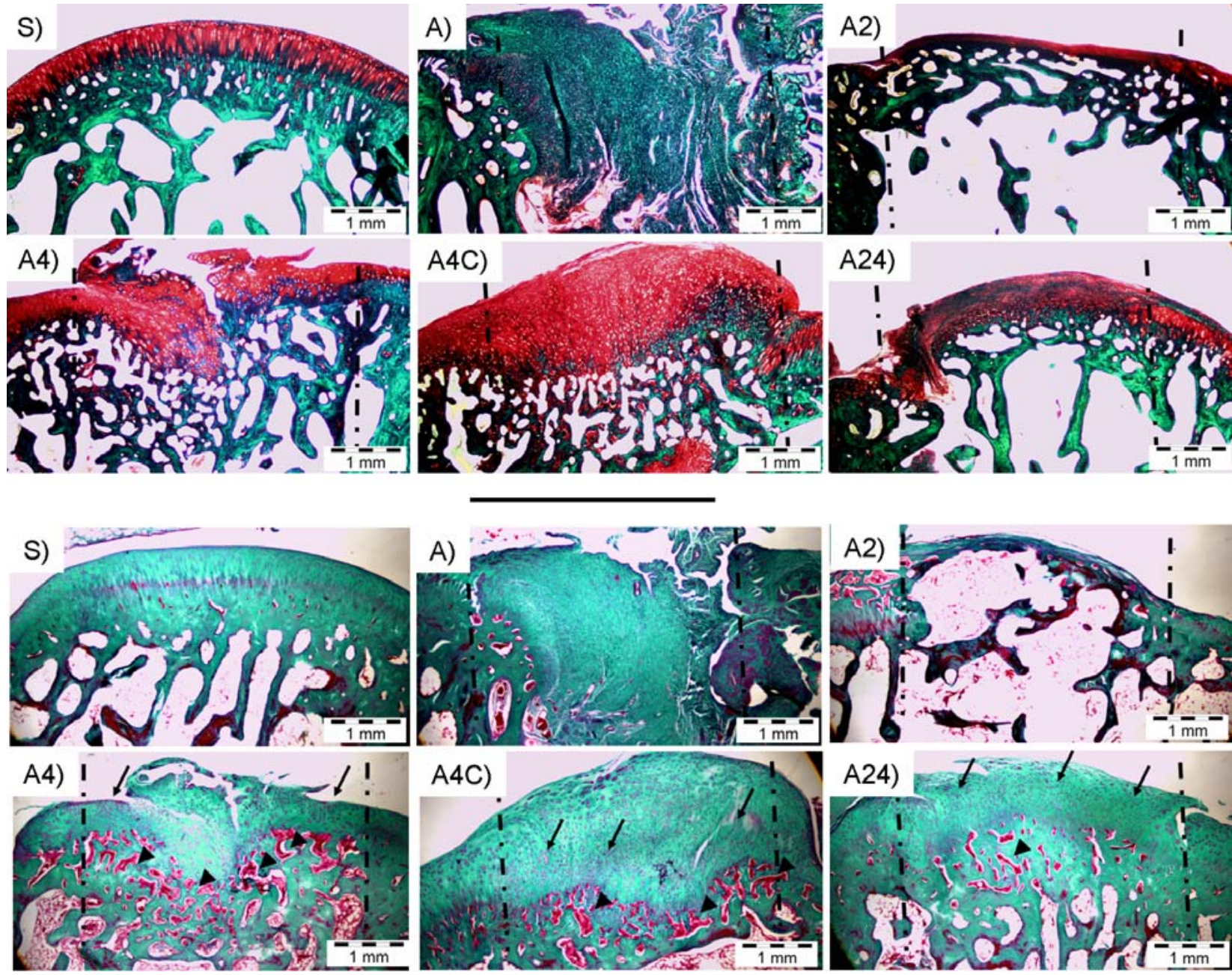

Fig. 6. Collagen stainings. Images up correspond to Sirius red staining and images down correspond to Masson's trichrome staining. S) Control untreated condyle. A) Alginate. A2) Alginate and rhBMP-2. A4) Alginate and rhBMP4. A4C) Alginate and rhBMP-4 and cells. A24) Alginate and rhBMP-2 and rhBMP-4. Dotted lines represent the limits of the injury. See in Masson's trichrome staining (A4, A4C and A24) arrows to show new cartilage formation and arrowheads to show vascularised new bone.

of these cells is disorganised, which correspond to fibrous tissue. rhBMP-2 treatment (A2) shows a defect fully filled with bone tissue, and similar histological appearance was observed in $\mathrm{A} 2 \mathrm{C}$ treatment (not shown). In contrast, rhBMP-4 treatment (A4) shows poor subchondral bone formation which was highly vascularised (see arrowheads in figure 6), and also shows moderate cartilage regeneration (see arrows in figure 6) in the surface of the defect area. The addition of cells in the implanted structure (A4C) induced a hypercellularity in the defect area but no improvement in the tissue quality. Last image shows the appearance of an A24 filled defect. The knees of this treatment show complete subchondral bone regeneration with vascularised areas (see arrowheads) and also cartilage tissue regeneration (see arrows). The newly formed cartilage was similar in thickness to adjacent cartilage and looked bonded to it, even if some samples showed fissures and discontinuities in the surface. Fig. 7 also shows Masson's trichrome staining. It shows higher magnification images of cartilage regeneration areas and different treatments. 

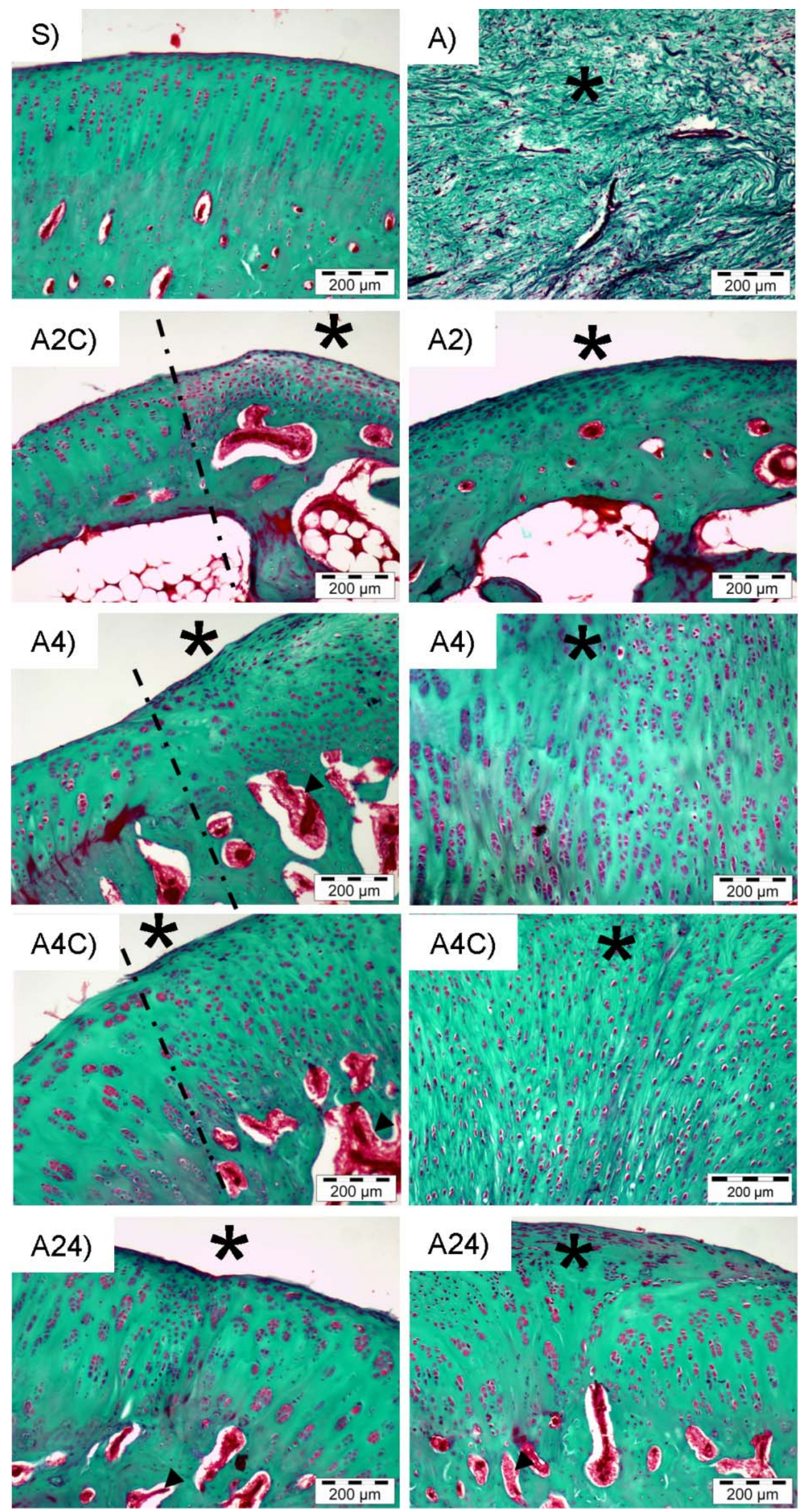

Fig. 7. Masson's trichrome staining. Detailed images of different treatments. S) control untreated condyle. A) Alginate. A2C) Alginate and rhBMP-2 and cells. A2) Alginate and rhBMP-2. A4) Alginate and rhBMP-4. A4C) Alginate and rhBMP-4 and cells. A24) Alginate and rhBMP-2 and rhBMP-4. All images show injury area (Asterisk) and some show the limit of the injury area (Dotted lines). See in A4, A4C and A24 arrowheads show vascularised new bone. 

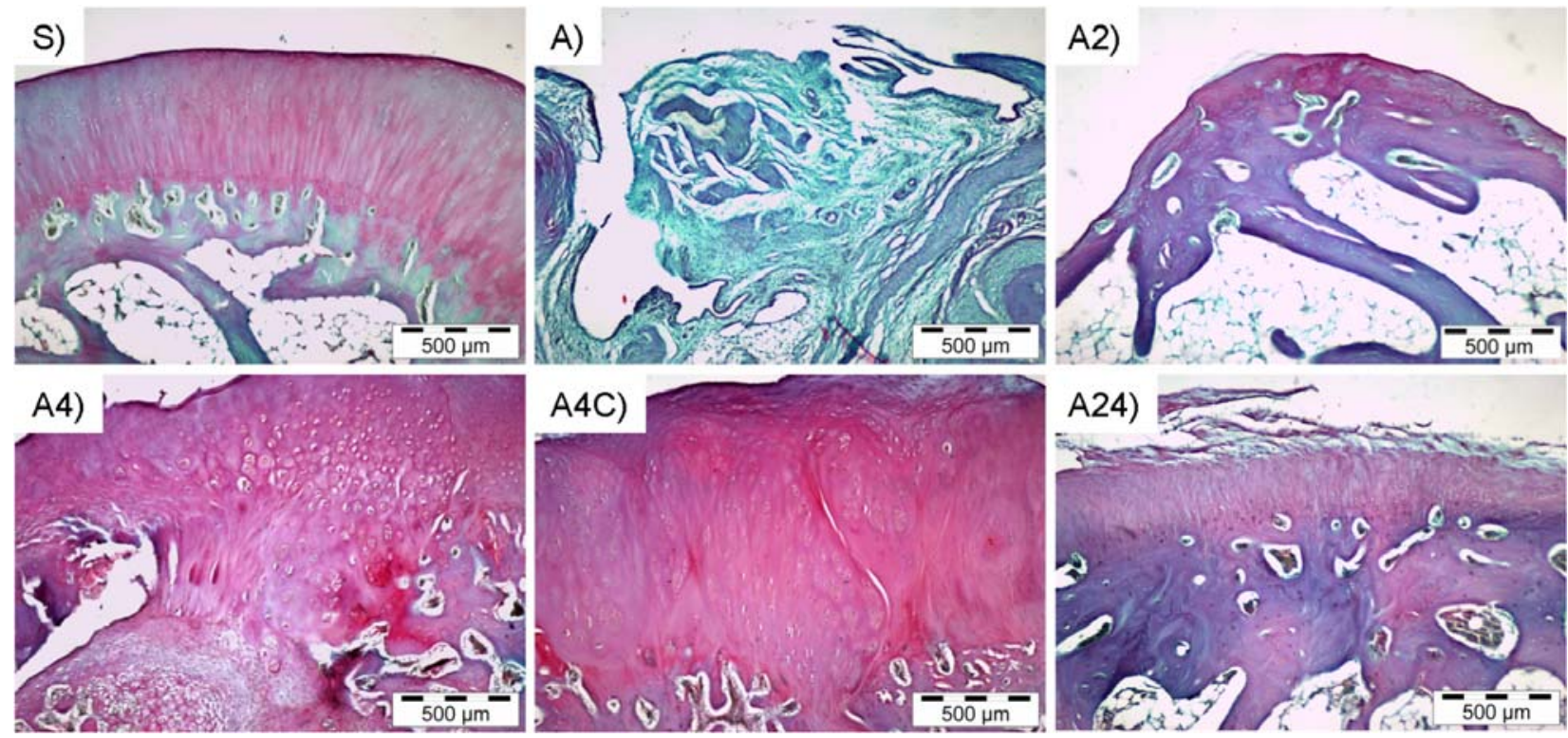

Fig. 8. Safranin O staining. S) Control untreated condyle. A) Alginate. A2) Alginate and rhBMP-2. A4) Alginate and rhBMP-4. A4C) Alginate and rhBMP-4 and cells. A24) Alginate and rhBMP-2 and rhBMP-4.
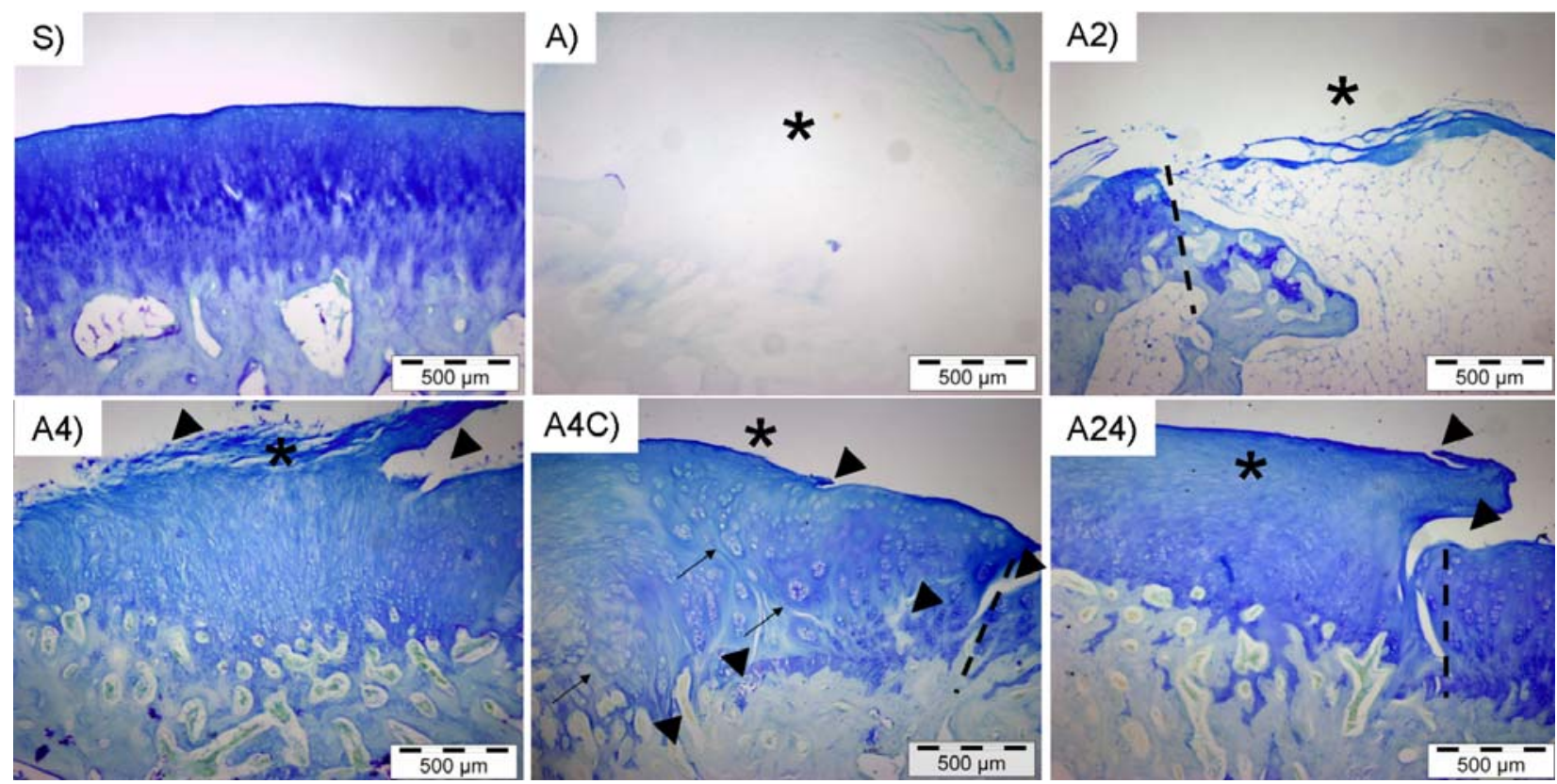

Fig. 9. Toluidine Blue staining. S) Control untreated condyle. A) Alginate. A2) Alginate rhBMP-2. A4) Alginate rhBMP-4. A4C) Alginate rhBMP-4 and cells. A24) Alginate rhBMP-2 and rhBMP-4. Dotted lines represent the limit of the injury. Asterisk shows the defect area. Arrows show cell clusters and arrowheads show fissures.

Fig. 8 shows Safranin O staining, which is a specific staining for cartilage proteoglycans. The first image shows the red staining corresponding to a control intact tissue (S). No proteoglycan staining was found in alginate A (AC not shown) and rhBMP-2 treatments A2 (A2C not shown). In contrast, all rhBMP-4 treatments show positive Safranin O staining. A4 treatment shows red staining deep inside the defect area suggesting poor bone tissue regeneration. $\mathrm{A} 4 \mathrm{C}$ treatment shows highly positive stained surface with a clearly higher thickness than the adjacent cartilage. A24 treated knees show positive Safranin O staining and seems to be the most similar to the adjacent tissue and to the undamaged cartilage tissue.

Fig. 9 corresponds to the performed toluidine blue staining, which is also a specific staining for cartilage proteoglycans (in this case blue staining, see figure 9S, undamaged cartilage tissue). The results obtained in this staining were quite similar to those ones obtained with Safranin O staining (Fig. 8). A4C shows cell clusters, while A4, A4C and A24 show homogeneous staining and irregularities and fissures in the cartilage surface.

\section{Histomorphometry}

We observed sample volumetric shrinkage due to histological processing. Thus, the mean injury area was quantified in $9.8 \mathrm{~mm}^{2}\left( \pm 0.2 \mathrm{~mm}^{2}\right)$. According to it, the harvested bone and cartilage volumes were estimated in non-damaged knees (S) (Fig. 10A). Fibrous tissue was the mainly observed one in Empty (E), Alginate (A) and Alginate/cells (AC) treatments (E: $2.3 \mathrm{~mm}^{2}\left( \pm 0.9 \mathrm{~mm}^{2}\right)$; 

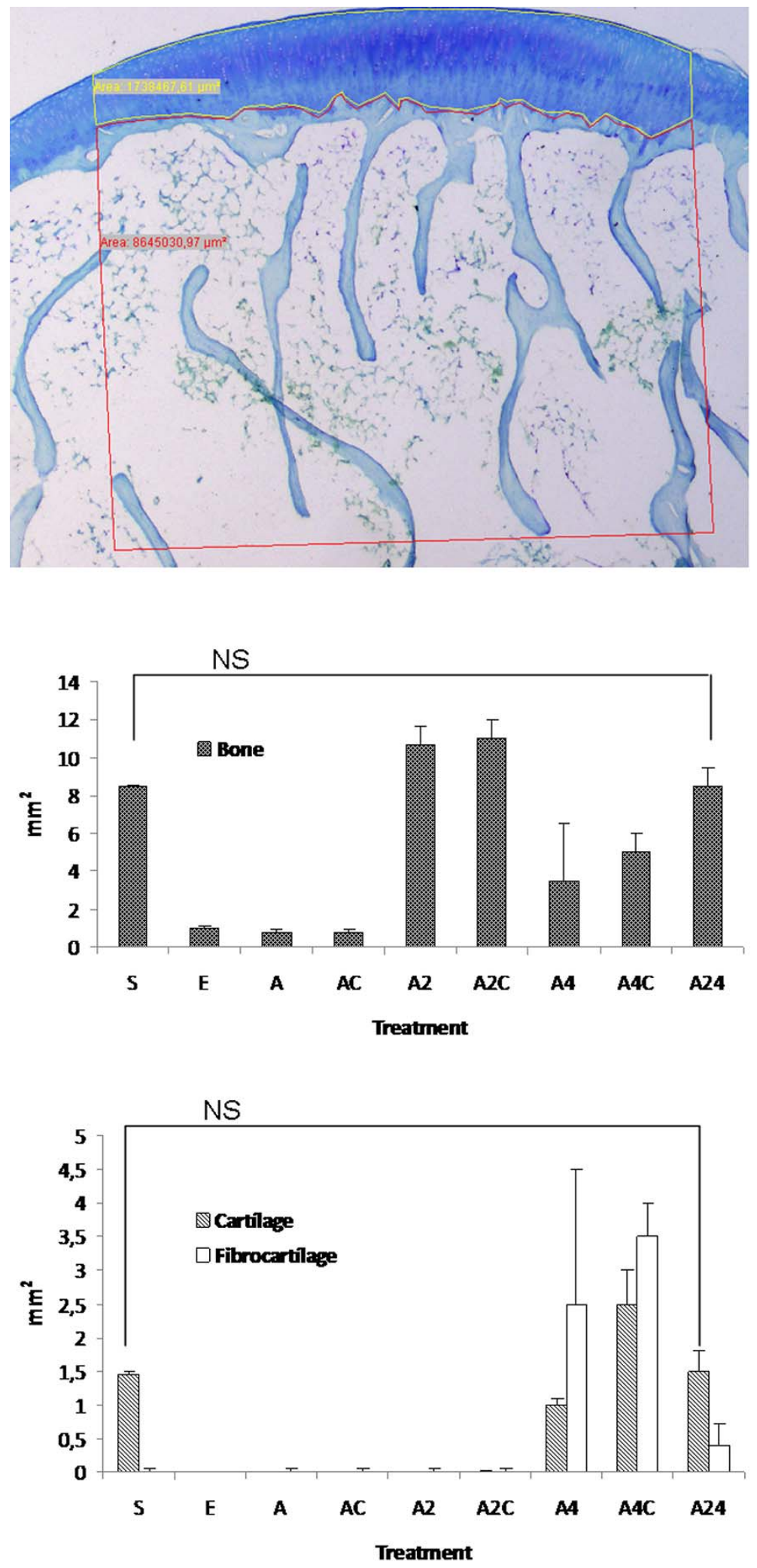

Fig. 10. Histomorphometry. Image is shown as an example of measurements performed and corresponds to a control sample. Histograms show the mean area values obtained in each treatment for bone, cartilage and fibrocartilage tissues (NS: statistically not significant with respect to control, $p<0.05)$.
A: $9.6 \mathrm{~mm}^{2}\left( \pm 0.2 \mathrm{~mm}^{2}\right)$; AC: $9.8 \mathrm{~mm}^{2}\left( \pm 0.2 \mathrm{~mm}^{2}\right)$. Fig. 10 shows the measurements obtained for bone, cartilage and fibrocartilage tissues. These data quantified the high amount of bone in $\mathrm{A} 2$ and $\mathrm{A} 2 \mathrm{C}$ and also the absence of cartilage tissue in them. Data also quantified cartilage formation in $\mathrm{A} 4$ and $\mathrm{A} 4 \mathrm{C}$. In this sense, the disparity in bone and fibrocartilage measurements observed in A4 samples is remarkable. In this A4 treatment, 4 samples show good bone formation, while 2 samples show high amount of fibrocartilage tissue with no bone regeneration.
Finally, data of A24 samples and non-damaged tissue (S) show no statistical differences in bone and cartilage values.

\section{Discussion}

Tissue engineering for osteochondral repair has received considerable attention in reconstructive surgery during the past decade. Most common strategies to engineer tissue involve the use of three components: growth factors, cells 
and carrier scaffolds. In this study, alginate gels are used as carrier for stromal cells and also as carrier for rhBMP2 and rhBMP-4 growth factors, in order to test this approach in rabbit osteochondral tissue regeneration and compare obtained data with previous in vitro and in vivo studies literature.

In vitro, several types of growth factors have been demonstrated to have chondrogenic activity whereas in vivo the most effective factors are those derived from the TGF superfamily (Van den Berg et al., 2001). Specifically, rhBMP-2 and rhBMP-4 are promising candidates for the promotion of chondrogenesis due to their role in chondrocyte differentiation and matrix maturation (Luyten et al., 1994, Miljkovic et al., 2008). In vitro, rhBMP-2 and rhBMP-4 improved the cartilage tissue formation, both in BMP overexpressing cells (Weber et al., 2002; Gelse et al., 2003; Steinert et al., 2003; Steinert et al., 2009) and exogenously BMP stimulated cells (Kramer et al., 2000; Martin et al., 2001; Majumdar et al., 2001; Valcourt et al., 2002; Gründer et al., 2004, Sekiya et al., 2005). In vivo, osteochondral and endochondral tissue regeneration has been obtained with rhBMP-4 overexpressing cells (Kuroda et al., 2006a) and also with rhBMP-2 as exogenously administrated growth factor with collagen sponge (Sellers et al., 2000) and gelatine sponge (Tokuhara et al., 2009) as carrier materials.

With regard to the employment of cells, the chondrogenic differentiation of mesenchymal stem cells in vitro is well documented and also it has been previously demonstrated that these cells are able to generate cartilaginous tissue in vivo (Liu et al., 2003; Pelttari et al., 2008). In this work bone marrow derived primary cell cultures are used, which have been successfully used in osteochondral tissue repair by other authors (Hannouche et al., 2007). In these cultures most, but not all, of the cells are mesenchymal stem cells, being more similar to expected in vivo environment than highly purified stem cell cultures.

We used calcium alginate as carrier material for several reasons. First, alginate is a biocompatible polysaccharide that is structurally similar to glycosaminoglycans present in cartilage (Langer et al., 1993; Mierisch et al., 2003; Park et al., 2005). Also, alginate gelation properties allow direct gel formation into the cartilaginous defects by simple addition of a calcium chloride solution. Thus, it is a fluid material that can fill any shape of defect and can incorporate various bioactive agents (e.g., Proteins and growth factors) (Gombotz et al., 1998; Tønnesen et al., 2002; Coviello et al. 2007; Lee et al., 2003).

Alginate has been extensively reported for cartilage tissue regeneration purposes. However, Wang et al. (Wang et al., 2003) reported that in vitro raw alginate properties have influence in material properties and in the encapsulated cell proliferation and differentiation processes. These facts perhaps explain why some authors (Mierisch et al., 2003; Shao et al., 2006) reported no osteochondral tissue regeneration using alginate encapsulated MSCs, while using similar in vivo approach Fragonas et al. (Fragonas et al., 2000) show good osteochondral tissue regeneration, and Erickson et al. (Erickson et al., 2002) show ectopic cartilage formation.
Which regard to alginate and BMPs in cartilage repair, the enhancement of chondrogenic properties using alginate as carrier material has been reported in the following cases: rhBMP-2 stimulated MSCs (Majumdar et al., 2001); rhBMP-2 and rhBMP-4 overexpressing MSCs (Steinert et al., 2003); and rhBMP-2 stimulated chondrocytes (Gründer et al., 2004).

With regard to the results obtained in this study, here we start with the performed control treatments. Figs. 4 and 5 show no defect filling and pannus formation in empty defects, and fibrous tissue formation in alginate treatment, which is in accordance with previous studies (Fragonas et al., 2000). On the other hand, we observe a different behaviour due to rhBMP-4 or rhBMP-2 treatment. The histology shows hyaline cartilage tissue in the composites with rhBMP-4, which agrees with previous studies of the rhBMP-4 in experimental animals (Kuroda et al., 2006b; Miljkovic et al., 2008). In these studies an improvement of the quality of the repaired tissue due to rhBMP-4 is reported. However we observe irregular amount of subchondral bone regeneration between A4 samples (compare A4 in all histological figures). This fact is reflected in the high standard deviation obtained in histomorphometrical study of A4 treatment (Fig. 10). On the contrary, according to literature the composites with rhBMP-2 improved subchondral bone repair (Sellers et al., 2000; Tokuhara et al., 2009), which is in agreement with our results. In our case, the histology shows that the treatment with rhBMP-2 and rhBMP-4 was the best of all tested approaches (see Fig. 10), with proper location and regeneration of subchondral bone and cartilage tissues.

With respect to the addition of stromal cells to alginate gel, previous in vivo assays performed with alginate gels and MSCs (the most similar than here presented ones) are once again contradictory: Fragona et al. show good osteochondral tissue regeneration while Mierisch et al. (Mierisch et al., 2003) show poor tissue regeneration. In our case, we firstly tested in vitro that cells were viable in the alginate gels in which would later be implanted (Fig. 1). In vivo we observed that cell addition in alginate treatments had influence only in the behaviour of $\mathrm{A} 4 \mathrm{C}$ composites, were cells induced the generation of more bone and cartilage than in $\mathrm{A} 4$ treatment. In fact $\mathrm{A} 4 \mathrm{C}$ shows similar amount of bone between samples and high amount of both cartilage tissue and fibrocartilage tissue formation (see Fig. 10), which exceeds the upper limit of defect area. However, in order to clarify the role of implanted cells in the reparative procedure other resources (mainly in vivo trackable marked cells (Mierisch et al., 2003; Shao et al., 2006) should be used.

\section{Conclusions}

The results indicate that alginate gel may act as an appropriate delivery vehicle for growth factors and cells. It is a perfectly biocompatible carrier and presents advantages like its easy application and proper defect filling. With this carrier, we have observed a differential behaviour between the evaluated proteins, being rhBMP2 superior in the restoration of the subchondral bone. In 
contrast, higher efficiency of rhBMP-4 in the restitution of cartilage was observed. The data taken as a whole show the difficulties that still remain to restore a structure composed by two differentiated elements: bone and articular cartilage.

\section{Acknowledgements}

The Funding sources supporting this publication are Ministerio de Sanidad (PIO-31485), Ministerio de Educación y Ciencia y Fondo Social Europeo (PTQ0502-02498 and Fundación PCM) and Ministerio de Ciencia e Innovación (CSD2009-00088). We thank Alba CuencaMoya (Noricum S.L.) and Virginia Gutierrez (Pharmakine) for their technical support.

\section{References}

Abarrategi A, García-Cantalejo J, Moreno-Vicente C, Civantos A, Ramos V, Casado JVS, Pérez-Rial S, LópezLacomba JL (2009) Gene expression profile on chitosan/ rhBMP-2 films: A novel osteoinductive coating for implantable materials. Acta Biomaterialia 5: 2633-2646.

Abarrategi A, Lópiz-Morales Y, Ramos V, Civantos A, López-Durán L, Marco F, López-Lacomba JL (2010) Chitosan scaffolds for osteochondral tissue regeneration. J Biomed Mater Res A 95: 1132-1141.

Buckwalter JA, Mankin HJ (1998) Articular cartilage: Degeneration and osteoarthrosis, repair, regeneration, and transplantation. Instr Course Lect 47: 487-504.

Chawla K, Klein TJ, Schumacher BL, Jadin KD, Shah BH, Nakagawa K, Wong VW, Chen AC, Masuda K, Sah RL (2007) Short-term retention of labeled chondrocyte subpopulations in stratified tissue-engineered cartilaginous constructs implanted in vivo in mini-pigs. Tissue Eng.13: 1525-1537.

Coviello T, Matricardi P, Marianecci C, Alhaique F (2007) Polysaccharide hydrogels for modified release formulations. J Controlled Release 119: 5-24.

Diduch DR, Jordan LC, Mierisch CM and Balian G. (2000) Marrow stromal cells embedded in alginate for repair of osteochondral defects. Arthroscopy 16: 571-577.

Erickson GR, Gimble JM, Franklin DM, Rice HE, Awad H, Guilak F (2002) Chondrogenic potential of adipose tissue-derived stromal cells in vitro and in vivo. Biochem Biophys Res Commun 290: 763-769.

Fragonas E, Valente M, Pozzi-Mucelli M, Toffanin R, Rizzo R, Silvestri F, Vittur F (2000) Articular cartilage repair in rabbits by using suspensions of allogenic chondrocytes in alginate. Biomaterials 21: 795-801.

Gelse K, Von der Mark K, Aigner T, Park J, Schneider H (2003) Articular cartilage repair by gene therapy using growth factor-producing mesenchymal cells. Arthritis Rheum 48: 430-441.

Gombotz WR, Wee SF (1998) Protein release from alginate matrices. Adv Drug Deliv Rev 31: 267-285.

Grande DA, Halberstadt C, Naughton G, Schwartz R, Manji R. (1997) Evaluation of matrix scaffolds for tissue engineering of articular cartilage grafts. J Biomed Mater Res 34: 211-220.

Gründer T, Gaissmaier C, Fritz J, Stoop R, Hortschansky P, Mollenhauer J, Aicher WK (2004) Bone morphogenetic protein (BMP)-2 enhances the expression of type II collagen and aggrecan in chondrocytes embedded in alginate beads. Osteoarthritis Cartilage 12: 559-567.

Hannouche D, Terai H, Fuchs JR, Terada S, Zand S, Nasseri BA, Petite H, Sedel L, Vacanti JP (2007) Engineering of implantable cartilaginous structures from bone marrow-derived mesenchymal stem cells. Tissue Eng 13: 87-99.

Hyllested J, Veje K, Ostergaard J (2002) Histochemical studies of the extracellular matrix of human articular cartilage - a review. Osteoarthritis Cartilage 10: 333-343.

Kramer J, Hegert C, Guan K, Wobus AM, Muller PK, Rohwedel J (2000) Embryonic stem cell-derived chondrogenic differentiation in vitro: activation by BMP2 and BMP-4. Mech Dev 92: 193-205.

Kuroda R, Usas A, Kubo S, Corsi K, Peng H, Rose T, Cummins J, Fu FH, Huard J (2006) Cartilage repair using bone morphogenetic protein 4 and muscle-derived stem cells. Arthritis Rheum 54: 433-442.

Langer R, Vacanti JP (1993) Tissue engineering. Science 260: 920-926.

Lee KY, Peters MC, Mooney DJ (2003) Comparison of vascular endothelial growth factor and basic fibroblast growth factor on angiogenesis in SCID mice. J Controlled Release 87: 49-56.

Lee SH, Shin H (2007) Matrices and scaffolds for delivery of bioactive molecules in bone and cartilage tissue engineering. Adv Drug Deliv Rev 59: 339-359.

Liu W, Cui L, Cao Y (2003) A closer view of tissue engineering in China: the experience of tissue construction in immunocompetent animals. Tissue Eng.9: 17-30.

Luyten FP, Chen P, Paralkar V, Reddi AH (1994) Recombinant bone morphogenetic protein-4, transforming growth factor-beta 1, and activin A enhance the cartilage phenotype of articular chondrocytes in vitro. Exp Cell Res 210: 224-229.

Majumdar MK, Wang E, Morris EA (2001) BMP-2 and BMP-9 promotes chondrogenic differentiation of human multipotential mesenchymal cells and overcomes the inhibitory effect of IL-1. J Cell Physiol 189: 275-284.

Malafaya PB, Silva GA, Reis RL (2007) Natural-origin polymers as carriers and scaffolds for biomolecules and cell delivery in tissue engineering applications. Adv Drug Deliv Rev 59: 207-233.

Marco F, Leon C, Lopez-Oliva F, Perez AJ, SanchezBarba A, Lopez-Duran Stern L (1992) Intact articular cartilage cryopreservation. In vivo evaluation. Clin Orthop Relat Res 283: 11-20.

Martin I, Suetterlin R, Baschong W, Heberer M, Vunjak-Novakovic G, Freed LE (2001) Enhanced cartilage tissue engineering by sequential exposure of chondrocytes to FGF-2 during 2D expansion and BMP-2 during 3D cultivation. J Cell Biochem 83: 121-128.

Melrose J, Chuang C, Whitelock J (2008) Tissue engineering of cartilages using biomatrices. J. Chem. Technol. Biotechnol 83: 444-463. 
Mierisch CM, Cohen SB, Jordan LC, Robertson PG, Balian G, Diduch DR (2002) Transforming growth factor$\beta$ in calcium alginate beads for the treatment of articular cartilage defects in the rabbit. Arthroscopy 18: 892-900.

Mierisch CM, Wilson HA, Turner MA, Milbrandt TA, Berthoux L, Hammarskjold ML, Rekosh D, Balian G, Diduch DR (2003) Chondrocyte transplantation into articular cartilage defects with use of calcium alginate: the fate of the cells. J Bone Joint Surg Am 85-A: 1757-1767.

Miljkovic ND, Cooper GM, Marra KG. (2008) Chondrogenesis, bone morphogenetic protein-4 and mesenchymal stem cells. Osteoarthritis Cartilage 16: 11211130 .

Nesic D, Whiteside R, Brittberg M, Wendt D, Martin I, Mainil-Varlet P (2006) Cartilage tissue engineering for degenerative joint disease. Adv Drug Deliv Rev 58: 300 322 .

O’Driscoll SW, Marx RG, Beaton DE, Miura Y, Gallay SH, Fitzsimmons JS (2001) Validation of a simple histological-histochemical cartilage scoring system. Tissue Eng 7: 313-320.

Park DJ, Choi BH, Zhu SJ, Huh JY, Kim BY, Lee SH (2005) Injectable bone using chitosan-alginate gel/ mesenchymal stem cells/BMP-2 composites. J Craniomaxillofac Surg 33: 50-54.

Pelttari K, Steck E, Richter W (2008) The use of mesenchymal stem cells for chondrogenesis. Injury 39: 58-65.

Raghunath J, Salacinski HJ, Sales KM, Butler PE, Seifalian AM (2005) Advancing cartilage tissue engineering: the application of stem cell technology. Curr Opin Biotechnol 16: 503-509.

Sekiya I, Larson BL, Vuoristo JT, Reger RL, Prockop DJ (2005) Comparison of effect of BMP-2,-4, and-6 on in vitro cartilage formation of human adult stem cells from bone marrow stroma. Cell Tissue Res 320: 269-276.

Sellers RS, Zhang R, Glasson SS, Kim HD, Peluso D, D'Augusta DA, Beckwith K, Morris EA (2000) Repair of articular cartilage defects one year after treatment with recombinant human bone morphogenetic protein-2 (rhBMP-2). J Bone Joint Surg Am 82: 151-160.

Shao X, Goh JC, Hutmacher DW, Lee EH, Zigang G (2006) Repair of large articular osteochondral defects using hybrid scaffolds and bone marrow-derived mesenchymal stem cells in a rabbit model. Tissue Eng.12: 1539-1551.

Sohier J, Moroni L, Van Blitterswijk C, de Groot K, Bezemer JM (2008) Critical factors in the design of growth factor releasing scaffolds for cartilage tissue engineering. Expert Opin Drug Deliv 5: 543-566.

Steinert A, Weber M, Dimmler A, Julius C, Schutze N, Noth U, Cramer H, Eulert J, Zimmermann U, Hendrich C
(2003) Chondrogenic differentiation of mesenchymal progenitor cells encapsulated in ultrahigh-viscosity alginate. J Orthop Res 21: 1090-1097.

Steinert AF, Proffen B, Kunz M, Hendrich C, Ghivizzani SC, Noth U, Rethwilm A, Eulert J, Evans CH (2009) Hypertrophy is induced during the in vitro chondrogenic differentiation of human mesenchymal stem cells by bone morphogenetic protein-2 and bone morphogenetic protein-4 gene transfer. Arthritis Res Ther 11: R148.

Tokuhara Y, Wakitani S, Imai Y, Kawaguchi A, Fukunaga K, Kim M, Kadoya Y, Takaoka K. (2010) Repair of experimentally induced large osteochondral defects in rabbit knee with various concentrations of Escherichia coliderived recombinant human bone morphogenetic protein2. Int Orthop 34: 761-767.

Tønnesen HH, Karlsen J (2002) Alginate in drug delivery systems. Drug Dev Ind Pharm 28: 621-630.

Tsutsumi S, Shimazu A, Miyazaki K, Pan H, Koike C, Yoshida E, Takagishi K, Kato Y (2001) Retention of multilineage differentiation potential of mesenchymal cells during proliferation in response to FGF. Biochem Biophys Res Commun 288: 413-419.

Valcourt U, Gouttenoire J, Moustakas A, Herbage D, Mallein-Gerin F (2002) Functions of transforming growth factor-beta family type I receptors and Smad proteins in the hypertrophic maturation and osteoblastic differentiation of chondrocytes. J Biol Chem 277: 33545-33558.

Van den Berg WB, Van der Kraan PM, Scharstuhl A, Van Beuningen HM. (2001) Growth factors and cartilage repair. Clin.Orthop Relat Res 391 Suppl: S244-250.

Van der Kraan PM, Buma P, Van Kuppevelt T, Van den Berg WB (2002) Interaction of chondrocytes, extracellular matrix and growth factors: relevance for articular cartilage tissue engineering. Osteoarthritis Cartilage 10: 631-637.

Wang L, Shelton RM, Cooper PR, Lawson M, Triffitt JT, Barralet JE (2003) Evaluation of sodium alginate for bone marrow cell tissue engineering. Biomaterials 24: 3475-3481.

Weber M, Steinert A, Jork A, Dimmler A, Thürmer F, Schütze N, Hendrich C, Zimmermann U (2002) Formation of cartilage matrix proteins by BMP-transfected murine mesenchymal stem cells encapsulated in a novel class of alginates. Biomaterials 23: 2003-2013.

Editor's note: All points raised by the reviewers of this paper were addressed by text changes. Hence, the is no "Discussion with Reviewers" section. 